\title{
Toetsing door de bestuurs- en de strafrechter van het voor inreisverboden geldende begrip 'ernstige bedreiging voor de openbare orde ${ }^{\text {** }}$
}

\author{
Nanda Ros \& Jim Waasdorp
}

\section{Inleiding}

Sinds de Terugkeerrichtlijn ${ }^{1}$ heeft Nederland te maken met het in artikel 11 van die richtlijn opgenomen inreisverbod. De opstellers van de Terugkeerrichtlijn hebben het inreisverbod gedefinieerd als een beslissing of handeling waarbij een onrechtmatig verblijvende onderdaan van een derde land (hierna: derdelander) de toegang tot en het verblijf op het grondgebied van de lidstaten voor een bepaalde termijn wordt verboden, samen met een terugkeerbesluit. ${ }^{2}$ De Nederlandse wetgever heeft een onderscheid gemaakt tussen lichte en zware inreisverboden. Er is sprake van een licht inreisverbod, indien daaraan de rechtsgevolgen van artikel 66a lid 6 van de Vreemdelingenwet 2000 (Vw 2000) zijn verbonden. Aan een zwaar inreisverbod zijn de rechtsgevolgen van artikel 66a lid 7 van de Vw 2000 verbonden. Dit is bijvoorbeeld het geval indien de derdelander volgens de staatssecretaris een ernstige bedreiging voor de openbare orde vormt (lid 7 onder c).

Wij merken op dat het inreisverbod in Nederland zowel in het vreemdelingenrecht als in het strafrecht een rol speelt. In het vreemdelingenrecht is het immers de staatssecretaris van Veiligheid en Justitie (hierna: de staatssecretaris) die een inreisverbod tegen een derdelander uitvaardigt. ${ }^{3}$ In het strafrecht is het inreisverbod aan de orde als een derdelander in weerwil van een al uitgevaardigd inreisverbod in Nederland verblijft. De derdelander kan dan strafrechtelijk worden vervolgd wegens overtreding van artikel 108 lid 6 van de Vw 2000 (bij een licht inreisverbod) of artikel 197 van het Wetboek van Strafrecht (Sr; bij een zwaar inreisverbod).

Uit de hierboven gegeven definitie van een inreisverbod blijkt dat deze maatregel altijd voor een bepaalde duur wordt uitgevaardigd. Die duur bedraagt volgens artikel 11 lid 2 van de Terugkeerrichtlijn in principe niet meer dan vijf jaar. Een inreisverbod kan echter meer dan vijf jaar bedragen, indien de derdelander een ernstige bedreiging vormt voor de openbare orde, de openbare veiligheid of de

* Deze bijdrage is op persoonlijke titel geschreven.

1 Richtlijn 2008/115/EG van 16 december 2008 over gemeenschappelijke normen en procedures in de lidstaten voor de terugkeer van onderdanen van derde landen die illegaal op hun grondgebied verblijven.

2 Art. 3 punt 6 van de Terugkeerrichtlijn.

3 Art. 66a van de Vreemdelingenwet 2000. 
nationale veiligheid. ${ }^{4}$ In deze bijdrage beperken wij ons tot het begrip 'ernstige bedreiging voor de openbare orde' en daarmee tot zware inreisverboden. Over de uitleg van dit begrip is al de nodige literatuur voorhanden. ${ }^{5}$ Toch merken wij dat in de praktijk discussie bestaat over het relevante toetsingsmoment voor de bestuurs- en de strafrechter. Daarom beantwoorden wij in deze bijdrage de volgende onderzoeksvraag: Moeten de bestuurs- en de strafrechter het bestaan van vorenbedoelde bedreiging toetsen naar het moment waarop het inreisverbod is uitgevaardigd of geldt dat de toetsing ook feiten en omstandigheden moet omvatten die zich nadien hebben voorgedaan?

Voor de beantwoording van deze vraag gebruiken wij een vreemdelingenrechtelijke en strafrechtelijke invalshoek. Daarbij komt ook het Unierecht aan de orde. In paragraaf 2 gaan wij in op de Terugkeerrichtlijn en het inreisverbod. Vervolgens schetsen wij in paragraaf 3 het toetsingskader aan de hand van jurisprudentie van het Hof van Justitie van de Europese Unie (Hof van Justitie). Dit kader bestaat uit het toetsingscriterium en het toetsingsmoment. Het criterium ontlenen wij aan het arrest van het Hof van Justitie inzake Zh. en O. ${ }^{6}$ Het toetsingsmoment baseren wij op zijn arrest inzake Oliveri. ${ }^{7}$ In de paragrafen 4 en 5 passen wij het geschetste toetsingskader toe. Paragraaf 4 gaat over het vreemdelingenrecht. In paragraaf 5 staat de strafrechtelijke invalshoek centraal. Wij sluiten in paragraaf 6 af met enkele bevindingen.

\section{Terugkeerrichtlijn en inreisverbod}

\subsection{Terugkeerrichtlijn}

De Terugkeerrichtlijn is op 24 december 2008 gepubliceerd in het Publicatieblad. ${ }^{8}$ De implementatie ervan heeft in Nederland plaatsgevonden door middel van de wet van 15 december 2011 tot wijziging van de $V_{w}$ 2000. Deze wet is op

4 Op 18 mei 2017 heeft advocaat-generaal Sharpston haar conclusie gegeven in de door de Nederlandse Hoge Raad aanhangig gemaakte zaak over de vraag wanneer de duur van een inreisverbod aanvangt (C-225/16). Sharpston concludeert dat die duur aanvangt op het moment dat de betrokken derdelander het grondgebied van de bij de Terugkeerrichtlijn betrokken lidstaten heeft verlaten. Zie ECLI:EU:C:2017:398. Op 26 juli 2017 heeft het Hof van Justitie EU arrest gewezen. Ook hij is van oordeel dat de duur van een inreisverbod aanvangt op het moment dat de betrokkene aan zijn terugkeerverplichting heeft voldaan. Opvallend is dat het Hof van Justitie EU overweegt dat 'het onrechtmatige verblijf van de betrokkene tot het tijdstip van de vrijwillige of gedwongen uitvoering van de terugkeerverplichting (...) wordt beheerst door het terugkeerbesluit en niet door het inreisverbod, dat pas vanaf dat tijdstip rechtsgevolgen teweegbrengt door het de betrokkene te verbieden om gedurende een bepaalde periode na zijn terugkeer het grondgebied van de lidstaten weer te betreden en er opnieuw te verblijven. Dit zou gevolgen kunnen hebben voor de huidige vervolgingspraktijk van het OM en de strafoplegging door de strafrechter. Zie ECLI:EU:2017:590.

5 Wij wijzen bijvoorbeeld op A. Pahladsingh en J.R.K.A.M. Waasdorp, 'Het inreisverbod en de openbare orde: een interne rechtsvergelijking tussen het vreemdelingenrecht en het strafrecht', Journaal Vreemdelingenrecht 2016/3, p. 81-96.

6 HvJ EU 11 juni 2015, Zh. en O., C-554/13, ECLI:EU:C:2015:377, JV 2015/209 m.nt. G.N. Cornelisse.

7 HvJ EG 29 april 2004, Oliveri, C-493/01, Jurispr., p. I-5295 e.v., ECLI:EU:C:2004:262.

8 PbEG L 348/98. 
31 december 2011 in werking getreden. ${ }^{9}$ Vanaf het verstrijken van de implementatietermijn op 24 december 2010 kunnen derdelanders zich echter al rechtstreeks op de Terugkeerrichtlijn beroepen. Voorwaarde voor rechtstreekse werking van de Terugkeerrichtlijn is wel dat de bepalingen waar rechtstreeks een beroep op wordt gedaan voldoende duidelijk en precies geformuleerd moeten zijn. $^{10}$

Uit artikel 2 lid 1 van de Terugkeerrichtlijn volgt dat deze richtlijn alleen van toepassing is op illegaal op het grondgebied van een lidstaat verblijvende onderdanen van derde landen. Als derdelander wordt blijkens artikel 3 lid 1 van de Terugkeerrichtlijn aangemerkt eenieder die geen burger is van de Europese Unie of onder het Unierecht inzake vrij verkeer valt. Voorbeelden zijn personen van Algerijnse, Chinese, Marokkaanse of Turkse nationaliteit die geen familielid zijn van een Unieburger die het recht van vrij verkeer uitoefent en die evenmin familielid zijn van onderdanen van een land uit de Europese Economische Ruimte of van Zwitserse onderdanen die rechten van vrij verkeer genieten die vergelijkbaar zijn met die van Unieburgers.

Voorafgaande aan de invoering van de Terugkeerrichtlijn voerde elk land zijn eigen terugkeerbeleid. Met de Terugkeerrichtlijn is beoogd binnen de Europese Unie op basis van gemeenschappelijke normen een doeltreffend verwijderings- en terugkeerbeleid te ontwikkelen, zodat derdelanders op een humane manier, met volledige eerbiediging van hun grondrechten en waardigheid, teruggezonden kunnen worden. ${ }^{11}$ De nationale maatregelen dienen effect te krijgen in de Europese dimensie, door middel van een inreisverbod dat de derdelander de toegang tot en het verblijf op het grondgebied van alle lidstaten ontzegt. ${ }^{12}$

\subsection{Inreisverbod}

\subsubsection{Vreemdelingenrecht}

De opstellers van de Terugkeerrichtlijn hebben in artikel 11 lid 2 van die richtlijn tot uitdrukking gebracht dat de duur van een inreisverbod in principe niet meer dan vijf jaar bedraagt. De lidstaten moeten voor de concrete vaststelling van de duur alle relevante omstandigheden individueel beoordelen en het evenredigheidsbeginsel in acht nemen. Zij mogen volgens de Europese Commissie wel als algemeen richtsnoer voor bestuurlijk handelen verschillende termijnen voor verschillende categorieën van situaties hanteren, bijvoorbeeld drie jaar als algemene regel, vijf jaar als sprake is van verzwarende omstandigheden (denk aan het herhaaldelijk overtreden van migratieregels) en één jaar als sprake is van verzachtende omstandigheden (denk aan het begaan van een overtreding uit onwetendheid). ${ }^{13}$ De Nederlandse wetgever heeft een dergelijke richtsnoer tot uitdrukking gebracht in artikel 6.5a van het $\mathrm{Vb} 2000$. Volgens die bepaling varieert de duur

10 HvJ EU 19 januari 1982, Becker, C-8/81 en HR 21 mei 2013 ECLI:NL:HR:2013:BZ3791, r.o. 3.4.

11 Punt 2 van de considerans van de Terugkeerrichtlijn.

12 Punt 14 van de considerans van de Terugkeerrichtlijn.

13 Handboek Terugkeer van de Europese Commissie (bijlage bij COM(2015) 6250 def.), p. 63. 
van een inreisverbod van één jaar (lid 2) tot twintig jaar (lid 6), waarbij als algemene regel twee jaar geldt (lid 1).

In situaties waarin sprake is van een ernstige bedreiging voor de openbare orde, kunnen de lidstaten volgens artikel 11 lid 2 van de Terugkeerrichtlijn een inreisverbod voor meer dan vijf jaar uitvaardigen. De Nederlandse wetgever heeft deze bepaling omgezet in artikel 66a lid 4 van de Vw 2000. Volgens de Europese Commissie kunnen de lidstaten bij de vaststelling van de bedoelde bedreiging met verschillende factoren rekening houden. Zij geeft als voorbeeld gepleegde strafbare feiten en administratieve delicten (denk aan het herhaaldelijk gebruik van valse identiteitspapieren, herhaaldelijke en opzettelijke schending van migratieregels). ${ }^{14}$ In artikel 6.5a lid 5 van het Vb 2000 heeft de Nederlandse wetgever vier factoren opgenomen waaruit volgens hem een ernstige bedreiging voor de openbare orde kan blijken. Dit zijn:

1 een veroordeling naar aanleiding van een geweldsdelict of opiumdelict;

2 een veroordeling tot een vrijheidsstraf wegens een misdrijf waartegen een gevangenisstraf van meer dan zes jaren is bedreigd;

3 de omstandigheid dat hem artikel $1 \mathrm{~F}$ van het Vluchtelingenverdrag wordt tegengeworpen; of

4 de oplegging van een maatregel als bedoeld in artikel 37a Sr.

Geen van deze - overigens niet-limitatief geformuleerde - factoren kan echter automatisch en op zichzelf beschouwd een ernstige bedreiging voor de openbare orde opleveren. In dit verband wijst de Europese Commissie erop dat de lidstaten te allen tijde de relevante omstandigheden individueel moeten beoordelen en het evenredigheidsbeginsel in acht moeten nemen. ${ }^{15}$ Maar hoe moeten zij dat doen? Welke uitgangspunten of maatstaven gelden hierbij? Het antwoord op deze vragen formuleren wij in paragraaf 3 . Voordat wij daaraan toekomen, geven wij eerst een korte inleiding over de betekenis van het inreisverbod in het strafrecht. Hierover gaat het vervolg van deze paragraaf.

\subsubsection{Strafrecht}

Indien een derdelander in Nederland verblijft terwijl hij weet of ernstige reden heeft te vermoeden dat tegen hem een inreisverbod als bedoeld in artikel 66a lid 7 van de Vw 2000 (een zwaar inreisverbod) is uitgevaardigd, maakt hij zich schuldig aan overtreding van artikel $197 \mathrm{Sr}$. Zoals hiervoor is beschreven, wordt een inreisverbod in beginsel opgelegd voor niet meer dan vijf jaren. Reden voor oplegging van een inreisverbod van maximaal vijf jaren kan zijn dat de derdelander naar het oordeel van de staatssecretaris een gevaar voor de openbare orde of de nationale veiligheid vormt. ${ }^{16}$ Een inreisverbod voor langer dan vijf jaren kan op grond van artikel 66a lid 4 Vw 2000 worden opgelegd indien de derdelander een ernstige bedreiging vormt voor de openbare orde. 
Met het oog op het bestanddeel 'tegen hem een inreisverbod is uitgevaardigd met toepassing van artikel 66a lid 7 van de Vw 2000' dient de strafrechter volgens de Hoge Raad te onderzoeken of de grondslag van het inreisverbod rechtmatig is. ${ }^{17}$ Is bijvoorbeeld een inreisverbod van meer dan vijf jaren opgelegd, dan dient de strafrechter aldus de rechtmatigheid van het oordeel dat de derdelander een ernstige bedreiging vormt voor de openbare orde te onderzoeken. Daarmee speelt de vraag wanneer een derdelander een gevaar voor de openbare orde dan wel een ernstige bedreiging voor de openbare orde, de openbare veiligheid of de nationale veiligheid vormt ook een belangrijke rol in het strafrecht. Hoe ver de strafrechter mag gaan in het onderzoek naar de rechtmatigheid van het inreisverbod wordt hieronder behandeld.

\section{Het toetsingskader}

\subsection{Toetsingscriterium}

\subsubsection{Het arrest Zh. en $O$.}

Naast artikel 11 lid 2 van de Terugkeerrichtlijn komt het begrip 'gevaar vormt voor de openbare orde' ook terug in artikel 7 lid 4 van de Terugkeerrichtlijn. Artikel 7 lid 4 betreft onder andere het afzien van het toekennen van een termijn voor vrijwillig vertrek aan degene tegen wie een terugkeerbesluit is uitgevaardigd en die een gevaar vormt voor de openbare orde. In het arrest $\mathrm{Zh}$. en O. heeft het Hof van Justitie zich uitgelaten over de vraag wanneer een derdelander een gevaar vormt voor de openbare orde. ${ }^{18}$ Het ging in deze zaak om het volgende. Tegen zowel $\mathrm{Zh}$. als O. was een terugkeerbesluit uitgevaardigd. Omdat de staatssecretaris van oordeel was dat zij een gevaar voor de openbare orde vormden, is hun geen termijn voor vrijwillig vertrek gegund en waren zij direct in vreemdelingenbewaring gesteld. Beide zaken zijn in hoger beroep voorgelegd aan de Afdeling bestuursrechtspraak van de Raad van State (Afdeling). Zij heeft beide zaken gevoegd behandeld en aanleiding gezien het Hof van Justitie te vragen om een uitleg van het begrip 'gevaar voor openbare orde' als bedoeld in artikel 7 lid 4 van de Terugkeerrichtlijn.

Het Hof van Justitie stelt in het arrest Zh. en O. voorop dat het begrip 'gevaar voor de openbare orde' niet in de Terugkeerrichtlijn is gedefinieerd. ${ }^{19}$ Volgens het Hof van Justitie dient een lidstaat het begrip gevaar voor de openbare orde in de zin van artikel 7 lid 4 van de Terugkeerrichtlijn per geval te beoordelen, teneinde na te gaan of de gedragingen van de betrokken derdelander een daadwerkelijk en actueel gevaar voor de openbare orde vormen. Wanneer een lidstaat daarbij steunt op een algemene praktijk of een vermoeden om vast te stellen dat sprake is van een dergelijk gevaar zonder dat naar behoren rekening wordt gehouden met de persoonlijke gedragingen van de derdelander en met het gevaar dat van die gedragingen uitgaat voor de openbare orde, gaat de lidstaat voorbij aan een indi-

17 HR 12 april 2016, ECLI:NL:HR:2016:616.

18 HvJ EU 11 juni 2015, Zh. en O., C-554/13, ECLI:EU:C:2015:377.

19 Arrest Zh. en O., punt 41. 
vidueel onderzoek van het betrokken geval en het evenredigheidsbeginsel. Daaruit volgt dat het enkele feit dat een derdelander wordt verdacht van het plegen van een naar nationaal recht als misdrijf strafbaar gesteld feit of daarvoor is veroordeeld, er op zichzelf geen rechtvaardiging voor kan vormen dat deze derdelander wordt beschouwd als een gevaar voor de openbare orde in de zin van artikel 7 lid 4 van de Terugkeerrichtlijn. ${ }^{20}$ Het begrip 'gevaar voor de openbare orde' als bedoeld in die bepaling veronderstelt hoe dan ook dat er, naast de verstoring die bij elke wetsovertreding plaatsvindt, sprake is van een werkelijke en actuele bedreiging die een fundamenteel belang van de samenleving aantast. ${ }^{21} \mathrm{Bij}$ de beoordeling of daarvan sprake is kunnen de volgende omstandigheden van belang zijn:

- de aard en de ernst van dat feit;

- het tijdsverloop sinds dat feit werd gepleegd;

- de omstandigheid dat die derdelander het grondgebied van die lidstaat aan het verlaten was toen hij door de nationale autoriteiten werd aangehouden;

- elk gegeven relevant dat betrekking heeft op de gegrondheid van de verdenking van het aan de betrokken derdelander verweten misdrijf. ${ }^{22}$

\subsubsection{Nederlandse jurisprudentie}

De Afdeling heeft op 2 juni 2016 bepaald dat de uitleg van het begrip 'gevaar voor de openbare orde' als bedoeld in artikel 7 lid 4 van de Terugkeerrichtlijn ook van toepassing is op het begrip 'ernstige bedreiging voor de openbare orde' als bedoeld in artikel 11 lid 2, tweede volzin, van de Terugkeerrichtlijn. ${ }^{23} \mathrm{Zij}$ overweegt daartoe dat de uitvaardiging van een inreisverbod voor de duur van meer dan vijf jaar in de zin van artikel 11 lid 2 van de Terugkeerrichtlijn een verdergaande maatregel is dan het onthouden van een vertrektermijn in de zin van artikel 7 lid 4 van de Terugkeerrichtlijn. Voor de uitvaardiging van een inreisverbod voor de duur van meer dan vijf jaar is daarom vereist dat sprake is van een werkelijke, actuele en voldoende ernstige bedreiging die een fundamenteel belang van de samenleving aantast. In zijn arrest van 14 februari 2017 sluit de Hoge Raad hierbij uitdrukkelijk aan. ${ }^{24}$

In aanvulling op haar uitspraak van 2 juni 2016 heeft de Afdeling op 8 november 2016 geoordeeld dat ook bij de toepassing van artikel 66a lid 7 onder b Vw 2000 bij inreisverboden van minder dan vijf jaren de staatssecretaris per geval moet beoordelen of het persoonlijke gedrag van de betrokken derdelander een werkelijke, actuele en voldoende ernstige bedreiging vormt die een fundamenteel belang van de samenleving aantast. Het bestaan van het in dat artikel genoemde gevaar voor de openbare orde moet volgens de Afdeling evenzeer worden beoordeeld overeenkomstig de eisen die het Unierecht daaraan stelt. ${ }^{25}$

HR 14 februari 2017, ECLI:NL:HR:2017:239, NBSTRAF 2017/106, NJB 2017/573, RvdW 2017/275. Zie ook de annotatie van mr. M.F. Wijngaarden bij dit arrest elders in deze editie.

ABRvS 8 november 2016, ECLI:NL:RVS:2016:3012. 


\subsubsection{Conclusie}

Gelet op het voorgaanden concluderen wij dat het voor inreisverboden geldende begrip 'ernstige bedreiging voor de openbare orde' als bedoeld in artikel 11 lid 2 van de Terugkeerrichtlijn en artikel 66a lid 4 Vw 2000 alsmede het begrip 'gevaar voor openbare orde' als bedoeld in artikel 66a lid 7 Vw 2000 zo moeten worden uitgelegd dat, naast de verstoring van de maatschappelijke orde die bij elke wetsovertreding plaatsvindt, in elk geval sprake moet zijn van een werkelijke, actuele en voldoende ernstige bedreiging, die een fundamenteel belang van de samenleving aantast. Daarbij geldt dat het persoonlijk gedrag van de derdelander een dergelijke bedreiging moet vormen.

\subsection{Toetsingsmoment}

Het tijdstip op basis waarvan moet worden bepaald of de bedoelde bedreiging actueel is, vormt in het strafrecht en het bestuursrecht regelmatig het voorwerp van discussie. In de Terugkeerrichtlijn zijn geen aanwijzingen te vinden over dit tijdstip. Het Hof van Justitie heeft zich hierover wel al uitgelaten in het arrest Oliveri. ${ }^{26}$ Dit arrest gaat over (het vrij verkeer van) Unieburgers en daarmee dus over een andere doelgroep dan die in onze bijdrage centraal staat, te weten: illegaal verblijvende derdelanders. Toch menen wij dat de overwegingen van het Hof van Justitie ook voor die derdelanders van belang kunnen zijn. In dit verband wijzen wij erop dat het Hof van Justitie in het arrest H.T. heeft overwogen dat de omvang van de bescherming die een samenleving aan haar fundamentele belangen wenst te bieden, niet mag verschillen naargelang van de juridische status van de persoon die deze belangen schaadt. ${ }^{27}$ Uit dit oordeel maken wij op dat verschillende openbare ordebegrippen op dezelfde wijze moeten worden uitgelegd. ${ }^{28}$ In het verlengde hiervan geldt het arrest Oliveri ook voor het tijdstip op basis waarvan moet worden bepaald of ten aanzien van een illegaal verblijvende derdelander de bedreiging actueel is.

Wat speelt er in de zaak die heeft geleid tot het arrest Oliveri? De heer Oliveri is in 1977 in Duitsland geboren en heeft de Italiaanse nationaliteit. Sinds zijn geboorte heeft hij ononderbroken in Duitsland verbleven. De heer Oliveri is echter al vele jaren aan drugs verslaafd. Hierdoor is hij besmet geraakt met het hivvirus en heeft hij chronische hepatitis $C$ opgelopen. Voorts heeft de heer Oliveri vele strafbare feiten gepleegd en is hij strafrechtelijk veroordeeld voor diefstal en illegale handel in verdovende middelen. In april 2000 is hij opnieuw gearresteerd en sindsdien bevindt hij zich in hechtenis. In november van hetzelfde jaar heeft

26 HvJ EG 29 april 2004, Oliveri, C-493/01, Jurispr., p. I-5295 e.v., ECLI:EU:C:2004:262.

27 HvJ EU 24 juni 2015, H.T., C-373/13, ECLI:EU:C:2015:413.

28 Vgl. P. Boeles, 'Gevaar voor openbare orde. Een nieuwe blik op de glijdende schaal', Asiel- en Migrantenrecht 2016/5, p. 223; M.F. Wijngaarden, 'Kroniek Openbare Orde', Asiel- en Migrantenrecht 2016/5, p. 241; A. Pahladsingh en J.R.K.A.M. Waasdorp, 'Het inreisverbod en de openbare orde: een interne rechtsvergelijking tussen het vreemdelingenrecht en het strafrecht', Journaal Vreemdelingenrecht 2016/3, p. 95-96. 
het Regierungspräsidium gelet op artikel 3 van richtlijn 64/221/EEG ${ }^{29}$ zijn uitzetting gelast en gedreigd hem naar Italië uit te zetten wegens de frequentie en de ernst van de begane strafbare feiten alsmede het concrete risico van recidive in de toekomst in verband met de drugsverslaving. Uit het dossier blijkt dat de medische dienst van het ziekenhuis van de strafinrichting bij brief van 20 juni 2001 - dus na het besluit tot uitzetting - heeft laten weten dat de heer Oliveri ernstig ziek is en dat hij binnenkort aan zijn ziekte zal bezwijken. Voorts heeft de heer Oliveri voor de nationale autoriteiten betoogd dat er geen gevaar voor recidive meer is, omdat hij volwassener geworden is door het harde leven in de gevangenis. In deze omstandigheden heeft het Verwaltungsgericht Stuttgart de prejudiciële vraag aan het Hof van Justitie gesteld of de nationale rechterlijke instanties bij de rechtmatigheidstoetsing van de uitzetting van Unieburgers ook rekening moeten houden met feitelijke gegevens en een gunstige ontwikkeling van de betrokkene van na het laatste besluit van de bevoegde instantie. ${ }^{30}$

Het Hof van Justitie oordeelt in het arrest Oliveri dat maatregelen van openbare orde uitsluitend op het persoonlijke gedrag van de betrokkene moeten berusten en dat het begrip openbare orde, afgezien van de storing van de sociale orde die bij elke wetsovertreding plaatsvindt, het bestaan veronderstelt van een werkelijke en genoegzaam ernstige bedreiging die een fundamenteel belang van de samenleving aantast. Voorts wijst het Hof van Justitie erop dat artikel 3 van richtlijn 64/221/EEG noch zijn jurisprudentie precieze aanwijzingen bevatten over het tijdstip op basis waarvan moet worden bepaald of die bedreiging actueel is. In de praktijk kan niet worden uitgesloten dat zich tussen een besluit tot uitzetting en de toetsing daarvan door de bevoegde rechter omstandigheden voordoen waardoor de bedreiging die het gedrag van de betrokkene voor de openbare orde vormde, verdwijnt of sterk vermindert. In dit verband wijst het Hof van Justitie erop dat op het tijdstip waarop de uitzetting plaatsvindt in beginsel aan de voorwaarde moet zijn voldaan dat de bedreiging actueel is. De Duitse praktijk, die ten tijde van belang in het arrest Oliveri inhield dat de nationale rechter bij de rechtmatigheidstoetsing van de uitzetting van een Unieburger geen rekening houdt met feiten die zich na het laatste overheidsbesluit hebben voorgedaan, kan volgens het Hof van Justitie afbreuk doen aan het recht van vrij verkeer. Deze vaststelling geldt volgens het Hof van Justitie in het bijzonder wanneer er een lange periode is verstreken tussen de datum van het uitzettingsbesluit en de datum waarop de bevoegde rechter dit besluit toetst. ${ }^{31}$

29 Richtlijn 64/221/EEG van de Raad van 25 februari 1964 voor de coördinatie van de voor vreemdelingen geldende bijzondere maatregelen ten aanzien van verplaatsing en verblijf, die gerechtvaardigd zijn uit hoofde van de openbare orde, de openbare veiligheid en de volksgezondheid. Volgens art. 3 lid 1 van deze richtlijn moeten de maatregelen van openbare orde uitsluitend berusten op het persoonlijke gedrag van de betrokkene.

30 Arrest Oliveri, punten 32-39.

31 Arrest Oliveri, punten 66,77-82. 


\section{Benadering in het vreemdelingenrecht}

\subsection{Het inreisverbod waartegen rechtstreeks beroep openstaat}

In het bestuursrecht geldt als regel dat de belanghebbende bij een besluit eerst bezwaar moet maken voordat hij beroep bij de bestuursrechter kan instellen. ${ }^{32}$ De wetgever heeft op deze regel echter een aantal uitzonderingen gemaakt. Twee daarvan zijn voor onze bijdrage van belang. Allereerst kan de wetgever in een bijzondere wet een uitzondering maken. Dit is het geval bij een inreisverbod dat is vervat in een besluit over een verblijfsvergunning asiel. Uit afdeling 3 van hoofdstuk 7 van de Vw 2000, getiteld 'Asiel', blijkt dat tegen een besluit inzake een dergelijke verblijfsvergunning geen bezwaar kan worden gemaakt, maar rechtstreeks beroep bij de bestuursrechter moet worden ingesteld. Volgens de Afdeling volgt een inreisverbod dat is vervat in dat besluit met het oog op concentratie van rechtsbescherming dezelfde rechtsmiddelen. ${ }^{33}$ Dit betekent dat de bezwaarfase in een dergelijk geval wordt overgeslagen. De tweede uitzondering die voor onze bijdrage van belang is, staat in bijlage 1 bij de Algemene wet bestuursrecht, getiteld 'Regeling rechtstreeks beroep'. ${ }^{34}$ Volgens deze bijlage kan tegen een separaat inreisverbod, dat wil zeggen een inreisverbod dat niet is vervat in een besluit inzake een verblijfsvergunning, geen bezwaar worden gemaakt. In plaats daarvan moet rechtstreeks beroep bij de bestuursrechter worden ingesteld. ${ }^{35}$

Deze constateringen zijn van belang met het oog op de toetsing door de bestuursrechter van het door de staatssecretaris uitgevaardigde inreisverbod. Het is vaste jurisprudentie van de Afdeling dat de bestuursrechter dit inreisverbod toetst naar de feiten die ten tijde van het nemen van dit besluit bekend waren of redelijkerwijs bekend behoorden te zijn. ${ }^{36}$ Deze wijze van toetsing betekent dus dat de bestuursrechter geen rekening houdt met feiten en omstandigheden die pas na het uitvaardigen van dit inreisverbod aan het licht komen. Een uitzondering hierop kan volgens ons worden gemaakt op basis van de hierboven beschreven overwegingen van het Hof van Justitie in het arrest Oliveri. Als de staatssecretaris zich in het besluit tot uitvaardiging van een inreisverbod op het standpunt stelt dat de derdelander een ernstige bedreiging voor de openbare orde vormt, dan moet hij motiveren dat diens persoonlijk gedrag een werkelijke, actuele en voldoende ernstige bedreiging vormt, die een fundamenteel belang van de samen-

32 Zie art. 7:1 lid 1 aanhef en art. 8:1 van de Awb.

33 ABRvS 15 juni 2012, JV 2012/328, ECLI:NL:RVS:2012:BW9111.

34 Deze bijlage is gebaseerd op art. 7:1 lid 1 aanhef en onder g van de Awb.

35 Daarbij is de duur van een inreisverbod niet relevant. Steeds staat tegen een separaat inreisverbod rechtstreeks beroep open. Zie in dit verband ABRvS 28 januari 2013, ECLI:NL:RVS: 2013:BZ0506, JV 2013/104.

36 ABRvS 6 november 2013, ECLI:NL:RVS:2013:1963; ABRvS 6 maart 2014, ECLI:NL:RVS: 2014:867; ABRvS 16 mei 2014, ECLI:NL:RVS:2014:1850; ABRvS 6 juni 2014, ECLI:NL:RVS: 2014:2100; ABRvS 31 juli 2014, ECLI:NL:RVS:2014:2960. 
leving aantast. ${ }^{37}$ Het arrest Oliveri biedt de bestuursrechter de ruimte om rekening te houden met feiten die zich na de besluitvorming hebben voorgedaan en die ertoe kunnen leiden dat de actuele bedreiging verdwijnt of sterk vermindert. Dit is vooral aan de orde als tussen de datum van het besluit en de toetsing daarvan door de bestuursrechter een lange periode is verstreken. Het is onzes inziens aan de (gemachtigde van de) derdelander om dergelijke feiten in beroep aan te voeren en zo nodig te onderbouwen. Vervolgens is het aan de staatssecretaris om hierover een standpunt in te nemen. Dit standpunt toetst de bestuursrechter op rechtmatigheid. Overigens verwachten wij niet dat in de praktijk ten aanzien van een inreisverbod dat is vervat in een besluit over een verblijfsvergunning asiel sprake zal zijn van een lange periode als bedoeld in het arrest Oliveri. De rechtbank moet in dat geval namelijk gelet op artikel 83b van de Vw 2000 uiterlijk binnen 4 of 23 weken na het instellen van beroep uitspraak doen.

Een voorbeeld ter illustratie. De derdelander is herhaaldelijk veroordeeld wegens straatroof, diefstal en mishandeling tot betaling van een geldboete of tot een gevangenisstraf, laatstelijk in april 2014. De gepleegde delicten komen allemaal voort uit een drugsverslaving. De staatssecretaris vaardigt in oktober 2016 een inreisverbod tegen de derdelander uit omdat hij gelet op de gepleegde delicten een ernstige bedreiging voor de openbare orde vormt. In beroep bij de bestuursrechter voert de derdelander aan dat hij zich na dit besluit tot een psychiater heeft gewend, een intensieve behandeling voor zijn drugsverslaving heeft ondergaan en die behandeling hem van zijn verslaving heeft afgeholpen. Ter staving hiervan legt de derdelander een medisch rapport over. Omdat de in het verleden gepleegde delicten uit de drugsverslaving voortkwamen, kan de omstandigheid dat hij niet meer verslaafd is relevant zijn voor de beoordeling van de actualiteit van de ernstige bedreiging. Het is aan de staatsecretaris om hierover in beroep een standpunt in te nemen en aan de bestuursrechter om dit standpunt op rechtmatigheid te toetsen.

\subsection{Het inreisverbod waartegen eerst bezwaar moet worden gemaakt}

Er doet zich één situatie voor waarin de derdelander tegen een inreisverbod eerst bezwaar moet maken voordat hij beroep bij de bestuursrechter kan instellen. Dit is het geval als het inreisverbod is vervat in een besluit over een verblijfsvergunning regulier. Uit afdeling 2 van hoofdstuk 7 van de Vw 2000, getiteld 'Regulier',

37 Volledigheidshalve wijzen wij wat betreft de actualiteit van de bedreiging enerzijds en de tegenwerping van art. 1(F) van het Vluchtelingenverdrag en de toepassing van richtlijn 2004/38/EG anderzijds nog op de jurisprudentie van de Afdeling die inhoudt dat de dreiging van een persoon van wie in rechte vaststaat dat ernstige redenen bestaan om te veronderstellen dat hij misdrijven heeft gepleegd als bedoeld in art. 1(F), aanhef en onder a, van het Vluchtelingenverdrag, naar zijn aard blijvend actueel is (zie ABRvS 16 juni 2015, ECLI:NL:RVS:2015:2008, JV 2015/225, NJB 2015/1353, $A B$ 2016/16, SEW 2015/654). In de verwijzingsuitspraak van 9 juni 2016 heeft de Rechtbank Den Haag haar twijfels geuit bij de juistheid van deze jurisprudentie van de Afdeling en hierover een prejudiciële vraag aan het Hof van Justitie gesteld (zie Rb. Den Haag 9 juni 2016, nr. 15/22024, ECLI:NL:RBDHA:2016:6389). Zie ook een kritische bespreking in de expert opinion van Migration Law Clinic: A. Beversluis e.a., Once a criminal, always a threat. Investigating whether the Dutch practice of applying Article 1F Refugee Convention criteria to Article 27 Citizenship Directive conforms with EU law, Amsterdam: VU Amsterdam 2016, in het bijzonder p. 21-23. 
blijkt dat tegen een besluit inzake een dergelijke verblijfsvergunning eerst bezwaar moet worden gemaakt. Ook voor een inreisverbod dat is vervat in dat besluit geldt volgens de Afdeling dat daartegen met het oog op concentratie van rechtsbescherming dezelfde rechtsmiddelen openstaan. ${ }^{38}$ Dit betekent dat de bezwaarprocedure in een dergelijk geval moet worden bewandeld. Die procedure biedt de derdelander rechtsbescherming door verlengde besluitvorming. Als hij bezwaar maakt, dan moet de staatssecretaris opnieuw beslissen. Daarbij is het de vraag of de staatssecretaris het inreisverbod kan handhaven. Als dat niet het geval is, dan moet hij het inreisverbod herroepen en zo nodig vervangen. ${ }^{39}$

In het primaire besluit waarbij de staatssecretaris een inreisverbod uitvaardigt, stelt hij vast dat de derdelander op dat moment een ernstige bedreiging voor de openbare orde vormt. Het primaire besluit gaat dus over de datum van de besluitvorming. Dit brengt mee dat het in bezwaar gaat om de datum van het besluit op het bezwaar. De staatssecretaris moet in bezwaar immers opnieuw beslissen. Hij moet dus in bezwaar rekening houden met feiten die zich tussen het primaire besluit en het besluit op bezwaar hebben voorgedaan. Als de derdelander feiten aanvoert op basis waarvan volgens hem niet langer de conclusie is gerechtvaardigd dat hij een ernstige bedreiging voor de openbare orde vormt, dan moet de staatssecretaris zijn besluit op bezwaar nemen met inachtneming van die feiten. ${ }^{40}$ In beroep toetst de bestuursrechter het besluit op bezwaar naar de feiten die ten tijde van het nemen van dit besluit bekend waren of redelijkerwijs bekend behoorden te zijn. Het toetsingsmoment is dus de datum waarop de staatssecretaris het besluit op bezwaar heeft genomen. Dit uitgangspunt geldt bijna absoluut. ${ }^{41}$ Net als in de twee situaties die wij in de vorige deelparagraaf hebben besproken, geldt dus ook bij het besluit op bezwaar tegen een inreisverbod dat is vervat in een besluit inzake een verblijfsvergunning regulier dat de bestuursrechter bij de toetsing van dit besluit op bezwaar geen rekening kan houden met feiten die pas na dit besluit zijn voorgevallen. Niettemin menen wij ook hier dat de bestuursrechter op basis van het arrest Oliveri de ruimte heeft om rekening te houden met feiten die zich na de besluitvorming hebben voorgedaan en die ertoe kunnen leiden dat de actuele bedreiging verdwijnt of sterk vermindert. In zoverre verwijzen wij naar hetgeen wij hierover in paragraaf 4.1 hebben opgemerkt.

\section{Benadering in het strafrecht}

\subsection{Het beginsel van formele rechtskracht}

In het kader van de bewijsvraag of de derdelander zich schuldig heeft gemaakt aan overtreding van artikel 197 Sr dient de strafrechter de rechtmatigheid van het inreisverbod te toetsen. De vraag is echter hoe indringend de strafrechter de rechtmatigheid van het inreisverbod moet toetsen. Centraal hierbij staat de leer

38 ABRvS 15 juni 2012, JV 2012/328, ECLI:NL:RVS:2012:BW9111.

39 Vgl. N. Verheij, 'Tussen toen en nu. Het relevante tijdstip voor besluitvorming in bezwaar en toetsing in beroep', Jurisprudentie Bestuursrecht plus 2003, p. 32.

40 Vgl. Verheij 2003, p. 32.

41 Vgl. Verheij 2003, p. 35-36. 
van de formele rechtskracht, wat inhoudt dat indien een bestuursrechtelijk besluit door de bestuursrechter bij onherroepelijke uitspraak in stand wordt gelaten, de strafrechter uit dient te gaan van de juistheid van die beslissing. Volgens de Hoge Raad kan slechts onder bijzondere omstandigheden aanleiding bestaan hierop een uitzondering te maken. ${ }^{42}$

Bij inreisverboden leidt dat ertoe dat indien de bestuursrechter zich bij onherroepelijke uitspraak heeft uitgelaten over het inreisverbod, het beginsel van formele rechtskracht eraan in de weg staat dat de strafrechter een verweer dat het inreisverbod in strijd is met het Unierecht, zelfstandig onderzoekt en daarop beslist. Evidente strijd met het Unierecht kan echter een bijzondere omstandigheid vormen waarin aanleiding wordt gezien hierop een uitzondering te maken. ${ }^{43}$

\subsection{Evidente strijdigheid van het inreisverbod met het Unierecht}

Over de vraag wanneer een inreisverbod evident in strijd is met het Unierecht heeft de Hoge Raad zich niet expliciet uitgelaten. Toch distilleren wij wel een bepaalde lijn uit een aantal arresten waarin de Hoge Raad zich heeft gebogen over het oordeel van het gerechtshof over de evidente strijdigheid van het inreisverbod met het Unierecht.

In de zaak die ten grondslag lag aan het arrest van de Hoge Raad van 12 april 2016 had de raadsvrouw in hoger beroep aangevoerd dat het enkele feit dat verdachte twee keer voor een Opiumwetdelict is veroordeeld, onvoldoende was om aan te nemen dat hij een ernstige bedreiging voor de openbare orde vormde. Volgens de Hoge Raad getuigde het oordeel van het gerechtshof dat de aan het verweer ten grondslag gelegde feiten en omstandigheden niet toereikend zijn voor de gevolgtrekking dat het tegen de verdachte uitgevaardigde inreisverbod evident in strijd is met rechtstreeks werkende bepalingen van Unierecht niet van een onjuiste rechtsopvatting. ${ }^{4}$

In de zaak die heeft geleid tot het arrest van de Hoge Raad van 14 februari 2017 had het gerechtshof geoordeeld dat de motivering van de oplegging van het inreisverbod in het licht van in het arrest $\mathrm{Zh}$. en $\mathrm{O}$. geformuleerde criteria onvoldoende is voor de conclusie dat in dit geval sprake is van een (ernstige) bedreiging van de openbare orde. Het gerechtshof heeft daarbij overwogen dat ten aanzien van de veroordelingen waarnaar in de beschikking wordt verwezen geldt dat, voor zover deze actueel zouden zijn, uit de gegeven motivering niet naar voren komt dat zij dermate ernstig zijn dat redelijkerwijs van een actuele en ernstige dreiging kan worden gesproken. Volgens de Hoge Raad was dit oordeel ontoereikend gemotiveerd, nu zonder nadere motivering het daarin besloten liggende oordeel van het gerechtshof dat in het onderhavige geval evident geen sprake was van een werkelijke, actuele en voldoende ernstige bedreiging die een fundamenteel belang van de samenleving aantast niet begrijpelijk is. ${ }^{45}$ 
Hoewel op grond van het arrest Zh. en O. in zijn algemeenheid wel kan worden gezegd dat een inreisverbod dat louter is gestoeld op veroordelingen onvoldoende is gemotiveerd, maken wij uit voornoemde arresten van de Hoge Raad op dat dit voor de vaststelling door de strafrechter dat het inreisverbod evident in strijd is met het Unierecht niet voldoende is. Slechts indien de strafrechter - zonder een onderzoek in volle omvang - vaststelt (en motiveert) dat de verdachte evident geen werkelijke, actuele en voldoende ernstige bedreiging die een fundamenteel belang van de samenleving aantast vormde, kan evidente strijdigheid met het Unierecht worden aangenomen.

Opmerking verdient dat de Hoge Raad recentelijk heeft bepaald dat ook wanneer de verdachte geen gebruik heeft gemaakt van de bestuursrechtelijke rechtsgang of wanneer een onherroepelijke uitspraak van de bestuursrechter in die rechtsgang niet kan worden afgewacht, in de strafzaak het hiervoor genoemde toetsingskader slechts aan het aannemen van de rechtmatigheid van het inreisverbod in weg staat als de strafrechter vaststelt dat in het voorliggende geval (feitelijk) evident geen sprake was van een werkelijke, actuele en voldoende ernstige bedreiging die een fundamenteel belang van de samenleving aantast. Indien het desbetreffende inreisverbod bij onherroepelijke uitspraak van de bestuursrechter toch wordt vernietigd nadat de veroordeling ter zake van overtreding van artikel $197 \mathrm{Sr}$ onherroepelijk is geworden, kan de verdachte een herzieningsaanvraag indienen. ${ }^{46}$

De Hoge Raad trekt hiermee de muren tussen de strafrechter en de bestuursrechter verder op. Vreemd vinden wij dit niet. Bezwaren tegen de motivering van het inreisverbod zouden bij uitstek bij de bestuursrechter moeten worden geuit. De bestuursrechter is immers de eerstaangewezene om te beoordelen of de staatssecretaris een ernstige bedreiging voor de openbare orde heeft kunnen aannemen, omdat de bestuursrechter een beter overzicht heeft op dit terrein en daarop ook een zekere jurisprudentiële lijn heeft kunnen ontwikkelen, hetgeen de rechtszekerheid bevordert. ${ }^{47}$ Daarbij speelt tevens een rol dat de bestuursrechter niet ambtshalve, maar slechts na daartoe aangevoerde gronden toetst of de motivering van het inreisverbod in het licht van de jurisprudentie van het Hof van Justitie tekortschiet. ${ }^{48}$ Indien de strafrechter wel ambtshalve de motivering van het inreisverbod zou toetsen, kan dit leiden dit tot een ongewenste doorkruising van de taakverdeling tussen de bestuursrechter en de strafrechter leiden. Zo wijst Machielse er terecht op dat een ruime toetsingsmogelijkheid door de strafrechter mogelijk bevordert dat een derdelander die constateert dat tegen hem een inreisverbod wordt uitgevaardigd waaraan een motiveringsgebrek kleeft zijn kruit droog houdt en daarvan in de bestuursrechtelijke procedure geen punt maakt. ${ }^{49}$

\subsection{Ex nunc}

Van belang is ten slotte te benadrukken dat het hier gaat om een zogeheten ex tunc-toetsing door de strafrechter. De strafrechter moet nagaan of het destijds

47 Punt 3.9 van de conclusie advocaat-generaal Machielse, ECLI:NL:PHR:2015:2637.

48 J.J.J. Sillen, 'De strafrechter en de leer van de formele rechtskracht', JBSelect 2014, 24, p. 371.

49 Punt 31 van de conclusie advocaat-generaal Vegter ECLI:NL:PHR:2016:1482. 
door de staatssecretaris genomen besluit tot uitvaardiging inreisverbod rechtmatig is genomen. Of de verdachte ook ten tijde van het overtreden van het inreisverbod of ten tijde van het onderzoek ter terechtzitting nog een ernstige bedreiging vormde voor de openbare orde is daarbij niet relevant. ${ }^{50}$

Klip is in zijn noot onder het arrest van de Hoge Raad van 13 juli 2010 echter een andere mening toegedaan. Hij betoogt in zijn noot dat in 2010 de justitiële documentatie waarop het in 1996 genomen besluit tot de ongewenstverklaring was gebaseerd te oud was om nog te kunnen dienen als basis voor de aanname dat het gevaar voor de openbare orde nog actueel was. ${ }^{51}$ Die mening van Klip delen wij niet. Het is niet aan de strafrechter om te beoordelen in hoeverre de derdelander ook thans een gevaar voor de openbare orde vormt en welke gevolgen dit al dan niet heeft voor de rechtmatigheid van het uitgevaardigde inreisverbod. Is de derdelander van mening dat zich inmiddels feiten hebben voorgedaan die er volgens hem toe moeten leiden dat geen sprake meer is van een actuele bedreiging voor de openbare orde, dan kan hij ingevolge artikel 66b lid 1 van de Vw 2000 de staatssecretaris te allen tijde verzoeken een uitgevaardigd inreisverbod op te heffen. Aan dit verzoek kan de derdelander ten grondslag leggen dat zich inmiddels feiten hebben voorgedaan die er volgens hem toe moeten leiden dat geen sprake meer is van een actuele bedreiging. Het is aan de staatssecretaris om op dit verzoek te beslissen. Daartegen kan de derdelander afzonderlijke (bestuursrechtelijke) rechtsmiddelen aanwenden.

\section{Bevindingen}

In deze bijdrage staat het voor inreisverboden geldende begrip 'ernstige bedreiging voor de openbare orde' en het relevante toetsingsmoment voor de bestuursen de strafrechter centraal. Op basis van het bovenstaande trekken wij de volgende conclusies. Zowel de bestuurs- als de strafrechter gaan ervan uit dat het begrip 'ernstige bedreiging voor de openbare orde' aldus moet worden uitgelegd dat, naast de verstoring van de maatschappelijke orde die bij elke wetsovertreding plaatsvindt, in elk geval sprake moet zijn van een werkelijke, actuele en voldoende ernstige bedreiging, die een fundamenteel belang van de samenleving aantast. Daarbij geldt dat het persoonlijk gedrag van de derdelander een dergelijke bedreiging moet vormen.

Wat betreft het toetsingsmoment geldt voor de bestuursrechter het volgende. De bestuursrechter toetst het besluit tot uitvaardiging van een inreisverbod of het besluit op bezwaar tegen die uitvaardiging naar de feiten die ten tijde van het nemen van dit besluit bekend waren of redelijkerwijs bekend behoorden te zijn. Met nieuwe feiten houdt hij dus geen rekening. Op basis van het arrest Oliveri heeft de bestuursrechter niettemin de ruimte om dat wel te doen met betrekking tot feiten die zich na de besluitvorming hebben voorgedaan en die ertoe kunnen leiden dat de actualiteit van de bedreiging verdwijnt of sterk vermindert. Het is 
onzes inziens aan de (gemachtigde van de) derdelander om dergelijke feiten in beroep aan te voeren en zo nodig te onderbouwen en aan de staatssecretaris om hierover een standpunt in te nemen. Dit standpunt toetst de bestuursrechter op rechtmatigheid. Zoals hiervoor aan het einde van alinea 5.3 reeds is opgemerkt, kan de derdelander de staatssecretaris ingevolge artikel 66b lid 1 van de Vw 2000 daarnaast te allen tijde verzoeken een uitgevaardigd inreisverbod op te heffen.

Tot slot geldt wat betreft het toetsingsmoment voor de strafrechter het volgende. De strafrechter moet nagaan of het destijds door de staatssecretaris genomen besluit tot uitvaardiging inreisverbod rechtmatig is genomen. Het persoonlijke gedrag van de derdelander ten tijde van het overtreden van het inreisverbod of ten tijde van het onderzoek ter terechtzitting is daarbij niet relevant. Gelet op het beginsel van formele rechtskracht dient de strafrechter bij de beoordeling van de rechtmatigheid van het inreisverbod terughoudendheid te betrachten. Slechts indien het inreisverbod evident in strijd is met het Unierecht, kan de strafrechter vaststellen dat het inreisverbod onrechtmatig is hetgeen in de strafzaak leidt tot een vrijspraak van overtreding van artikel $197 \mathrm{Sr}$. De vaststelling dat de motivering van de staatssecretaris voor de uitvaardiging van het inreisverbod tekortschiet in het licht van de jurisprudentie van het Hof van Justitie is niet voldoende voor evidente strijdigheid met het Unierecht. 